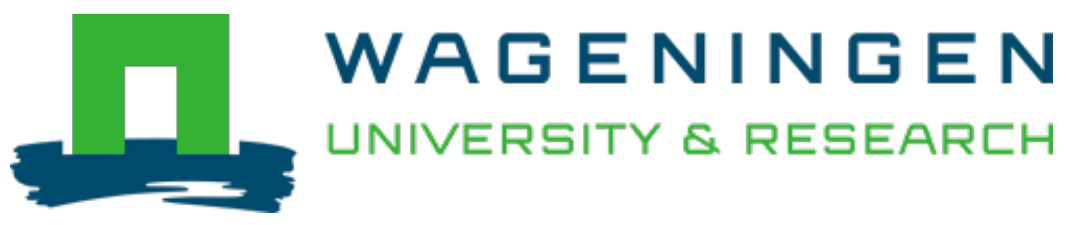

\title{
Increase of light transmission by 10\% in the Venlo-type greenhouse : From design to results of a cucumber experiment
}

\author{
Acta Horticulturae \\ Kempkes, F.; Janse, J.; Swinkels, G.L.A.M.; Hemming, S. \\ https://doi.org/10.17660/ActaHortic.2020.1296.70
}

This article is made publicly available in the institutional repository of Wageningen University and Research, under the terms of article $25 \mathrm{fa}$ of the Dutch Copyright Act, also known as the Amendment Taverne. This has been done with explicit consent by the author.

Article 25 fa states that the author of a short scientific work funded either wholly or partially by Dutch public funds is entitled to make that work publicly available for no consideration following a reasonable period of time after the work was first published, provided that clear reference is made to the source of the first publication of the work.

This publication is distributed under The Association of Universities in the Netherlands (VSNU) 'Article $25 \mathrm{fa}$ implementation' project. In this project research outputs of researchers employed by Dutch Universities that comply with the legal requirements of Article $25 \mathrm{fa}$ of the Dutch Copyright Act are distributed online and free of cost or other barriers in institutional repositories. Research outputs are distributed six months after their first online publication in the original published version and with proper attribution to the source of the original publication.

You are permitted to download and use the publication for personal purposes. All rights remain with the author(s) and / or copyright owner(s) of this work. Any use of the publication or parts of it other than authorised under article $25 \mathrm{fa}$ of the Dutch Copyright act is prohibited. Wageningen University \& Research and the author(s) of this publication shall not be held responsible or liable for any damages resulting from your (re)use of this publication.

For questions regarding the public availability of this article please contact openscience.library@,wur.nl 


\title{
Increase of light transmission by $10 \%$ in the Venlo-type greenhouse: from design to results of a cucumber experiment
}

\author{
F. Kempkesa, J. Janse, G.L.A.M. Swinkels and S. Hemming \\ Wageningen University \& Research, Greenhouse Horticulture, Wageningen, The Netherlands.
}

\begin{abstract}
During the autumn and winter at higher latitudes natural light is the limiting factor for crop growth in greenhouses. A new greenhouse and cultivation concept has been developed to increase the overall light transmission of the greenhouse with at least $\mathbf{1 0 \%}$. Several innovative elements have been considered: diffuse glass with an anti-reflective coating, high transmission under wet conditions, increased glass panel size, improved screen material, $\mathrm{V}$-shaped screen installation, highly reflective coatings on constructional parts. This has led to an integral design and realization of a $500 \mathbf{~ m}^{2}$ greenhouse in 2016 at Wageningen University \& Research in the Netherlands. In an earlier study Kempkes et al. (2017) presented the final results of the new Winterlight greenhouse design. According to model calculations a 10.5\% gain in PAR sum could be reached during winter. The greenhouse concept has been tested by growing cucumbers. In cooperation with growers a growing strategy has been developed. Besides maximizing the use of natural light, energy consumption was reduced using two movable screens, a balance ventilation system with heat recovery during dehumidification and growing according to the principles of the 'New Cultivation Strategies'. Light transmission has been measured and was compared with raytracing simulations. Especially during diffuse light conditions, the accuracy was within $1 \%$. On the long-term the difference between calculated and measured PAR sum was below $3 \%$. Greenhouse climate and energy consumption have been compared with those of commercial growers. Energy savings up to $40 \%$ and production increases up to $30 \%$ were reached growing cucumber 'High Power' in the new greenhouse compared to commercial greenhouses. Light transmission was increased with more than $10 \%$. Energy use was $176 \mathrm{kWh} \mathrm{m}^{-2}$ for heat and $2.5 \mathrm{kWh} \mathrm{m}^{-2}$ electricity for the fans of the balance ventilation and heating system. Additionally, $10.2 \mathrm{~kg} \mathrm{~m}^{-2} \mathrm{of} \mathrm{CO}_{2}$ was purchased. Cucumber production was $120 \mathrm{~kg} \mathrm{~m}^{-2}$ with good quality (284 pcs). An average Dutch grower using the high-wire system uses about $282 \mathrm{kWh} \mathrm{m}^{-2}$ gas equivalents producing around $95 \mathrm{~kg} \mathrm{~m}^{-2}$.
\end{abstract}

Keywords: greenhouse design, covering material, simulation model, diffuse light, cucumber, re-rooting

\section{INTRODUCTION}

Especially during winter months, it is important to achieve high crop production with high quality in higher latitudes. During this period, product prices are generally high, therefore, winter production is important for growers. In the Netherlands, the average solar radiation sum in winter is ten times lower than in the summer leading to light being a limiting growth factor. Nevertheless, it is important to utilize the available natural light as much as possible for crop production. Research by Marcelis et al. (2014) has shown that especially in winter, $1 \%$ more light gives $0.8-1 \%$ more production for cucumber. In earlier studies Hemming et al. (2004) showed the importance of optimum use of natural light. Janssen et al. (2006) carried out calculations on the effect of greenhouse shape on light transmission. The importance of diffuse light and diffuse coverings has been shown in various studies for various

aE-mail: Frank.Kempkes@wur.nl 
crops (e.g., Hemming et al., 2008; Dueck et al., 2012; Li et al., 2014). The role of light increasing anti-reflection coatings for horticultural glass has been described by Hemming et al. (2011) and the effect of condensation against the greenhouse cover has earlier been investigated by Stanghellini et al. (2012).

Natural sunlight is for free and should be used as much as possible for crop production in greenhouses (Hemming et al., 2004). Especially during winter, every Joule of sunlight is free energy input into the greenhouse reducing heating costs. The amount of light available to the crop in winter depends on many factors interacting with each other. These factors are: greenhouse design, layout of the greenhouse (installations and applied materials inside the greenhouse), covering material and type of condensation at the cover or screen. After natural light has entered the greenhouse, crop parameters such as plant structure, plant development stage and leaf area index, plant spacing and crop orientation also have a major impact on light interception. In this research, as well technical aspects of light entering through the greenhouse roof, as crop related aspects to increase production, are also taken into account.

In an intensive optical modelling study the above mentioned single and combined factors have been calculated with ray-tracing models. In that modelling study a theoretically optimum greenhouse roof design has been identified (Kempkes et al., 2018). Afterwards, a consortium of greenhouse suppliers (greenhouse construction, glass and coatings, screens and breeder) developed and built the new "Winterlight greenhouse". The goal was to gain at least 10\% more natural light in winter (October-March) inside the greenhouse and to gain at least $10 \%$ more production. In this paper, the results of measurement results of light penetration and interception, greenhouse climate, energy consumption and cucumber crop growth and development in the Winterlight greenhouse are presented.

\section{MATERIALS AND METHODS}

\section{Greenhouse light transmission and light sum}

The new greenhouse Winterlight greenhouse concept is described by Kempkes et al. (2018). It had been constructed at WUR, Bleiswijk, The Netherlands. A PAR grid of 12 sensors (PQS1 PAR Quantum Sensor, Kipp \& Zonen) are mounted in a roof span between 2 bars at 50 $\mathrm{cm}$ below the trellis bar. In addition, there is one sensor placed outside on top of the greenhouse as a reference measurement. Through this mounting, the sensors also measure the effects of screen usage on the total transmission. The sensors are connected to a data logger (DT / 500, Datataker) and an average measurement of every minute is stored. The results of the PAR measurements were compared with calculations of the ray-tracing model for these exact locations (Kempkes et al., 2018). This makes it possible to verify whether the measurements correspond to the ray-tracing calculations and if so, the light sum over the year can be calculated depending on the screen positions. A greenhouse of one of the commercial growers was equal and served as reference greenhouse: a Venlo-type greenhouse with a $8 \mathrm{~m}$ trellis bar with a standard white powder coated substructure. While in the Winterlight greenhouse two movable non diffusing screens (new prototype version comparable to a Luxous 4317, Ludvig Svensson) were used, the commercial grower 1 has one Luxous 4317 screen and a RES 10 (De Ridder Screens) with a ca. 1\% less hemispherical light transmission. This grower is situated $2 \mathrm{~km}$ south-west of the WUR test facility in Bleiswijk and therefore enables use of the same outside climate for long-term calculations. For the transmission of this greenhouse, the transmission of the reference greenhouse was used with a hemispherical transmission of $73 \%$ for the Luxous 4317 and $72 \%$ for the RES 10 screen. The transmission of the commercial grower 2 greenhouse is slightly lower since he had a non-powder coated substructure, he had two screens, a Luxous 4317 screen and a shading screen PH70 (Bonar Phormium). Commercial grower 2 is located more than $30 \mathrm{~km}$ away and is indirectly included in this comparison, given the great distance to the WUR location. Therefore, we used the Bleiswijk data with but the grower's screen strategy. The realized climate of the commercial companies and the Winterlight greenhouse were exported from the climate computers on a 5-min basis. 


\section{Dehumidification}

The greenhouse is equipped with a Van Dijk heating (AVS-WTW) dehumidification unit with heat recovery (Kempkes et al., 2017). This unit is controlled depending on the actual moisture content. The unit is equipped with 2 fans. One extracts the humid greenhouse air centrally from the rear of the greenhouse and blows it through an air-to-air heat exchanger. A second fan blows in outside air through the same counter-flow heat exchanger and is thereby preheated. Also, a valve is installed that allows the greenhouse air to be recirculated inside the greenhouse or to be recirculated only partial in combination with outside air. When the unit is switched on, a minimum fan speed of $30 \%$ is maintained for the exhaust fan. The blower fan always has a fan speed $10 \%$ higher than the exhaust fan to keep the greenhouse a little overpressured. When dehumidification is started, the outside valve controlling the supply of outside air is set to a minimum of $50 \%$. When the demand for dehumidification increases, the outside valve is fully opened firstly, followed by turning on the fans. Behind the air-to-air heat exchanger, the air is led through a post-heating block. If necessary, the air is heated to greenhouse air temperature. The heat input was measured with a heat counter. This postheating system is not used to heat the greenhouse.

\section{Energy and climate}

The control of the climate is based on the crop status and on the insights of 'The New Cultivation Strategies', focussing on as much as possible a balance of ratio light sum and 24-h temperature average. The climate was adjusted in mutual consultation based on a biweekly visit by the growers. Energy use was determined measuring the heat input using a heat meter. Because the greenhouse is only $515 \mathrm{~m}^{2}$, side wall effects are considerable. To compensate for the heat loss through side walls, the side wall heating is controlled separately. For a greenhouse of $4 \mathrm{ha}$, an average greenhouse size in the Netherlands, the side walls contribute approximately $10 \%$ to the total heat loss of the greenhouse. For comparison with nurseries in practice, the heat consumption of the horizontal part of the greenhouse has been increased by $10 \%$ as the facade loss of a normal greenhouse. Grower 1 has an area of 4.2 ha and grower 2 has an area of 2.5 ha. The energy consumption (total input for the entire nursery) of these growers are registered on a weekly basis. The realized greenhouse climate parameters of the growers (one and two) have been exported from their climate computer so that they can be compared with the climate of the Winterlight greenhouse.

\section{Re-rooting}

A high-wire cucumber cultivation has typically two crop cycles per year. The first growing period is from mid-January to mid-June followed by a period from mid-June to the end of October or mid of November. This summer change takes place exactly in the period of the year with highest solar radiation and as a result there is no production for a minimum of 2.5 weeks. While looking for production maximization, an attempt was made to realise one crop cycle almost year round. It is known that the length of the plant, up to more than $20 \mathrm{~m}$ at the end of the cycle, becomes too long for transporting all the required water and nutrition from the root environment to the top of the plant. Re-rooting is a solution for this problem. New roots can be created when a stem with a leaf axillary is placed in an organic substrate and moistened. Because of this re-rooting, it should be possible to use one crop cycle instead of two crop cycles and as a result there will be no production stop in the summer.

The crop in the Winterlight greenhouse was re-rooted on April 26 and June 14. For this purpose, special developed trays (Beekenkamp) filled with coco fibre have been used as shown in Figure 1. These are placed directly across the stone wool slab, where a piece has been removed from the plastic sealing of the substrate slab to allow drainage water to drain from the re-root area from the tray to the stone wool slab. It is important that for every stem placed in the tray at least one leaf axillary is always placed into the tray because the roots start to develop directly above the leaf axillary. Because a planting density of $1.67 \mathrm{stems} \mathrm{m}^{-2}$ was maintained at the start of the cultivation, which was doubled on February 22, two stems per plant are re-rooted in the substrate. When placing the stems in the tray, the substrate is filled directly above the stems and provided with a separate dripper. A second drip line has been 
installed for this purpose, so that the drippers can be maintained at the old position on the stone wool block.

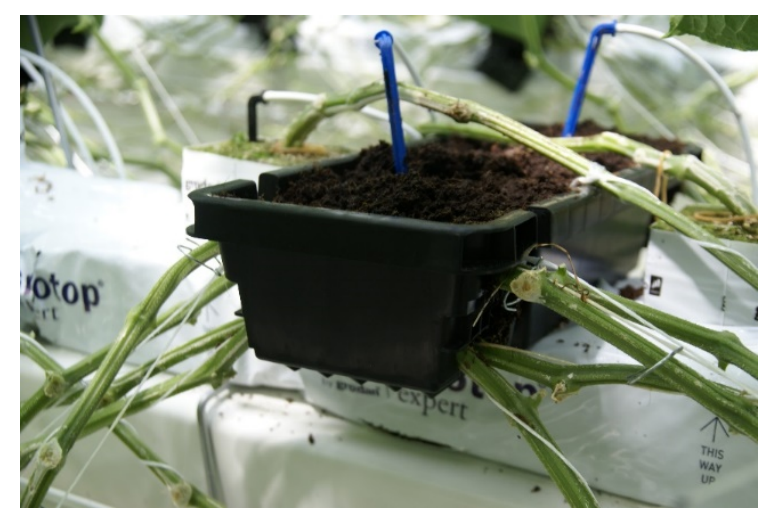

Figure 1. The re-root tray placed on the stone wool slab with 2 times 2 stems placed in the tray. The lower two stems are of re-rooting date of April 26 and the upper two stems of the re-rooting date of June 14.

\section{Crop growth and production}

The production (number of fruits and weight) and the quality (class 1 and 2) was determined during each harvest. The cucumber crop (cultivar 'Hi-Power', BASF-Nunhems) was transplanted December 28, 2017 with a density of 1.67 plants $\mathrm{m}^{-2}$ and the last harvest was November 21, 2018. The results of the commercial growers were provided on a weekly basis. Grower 1 transplanted December 22, 2017 the cultivar 'Proloog' (Rijk Zwaan) with a plant density of 1.5 plants $\mathrm{m}^{-2}$ and increased the number of stems in two steps to 3 stems m-2. The first cycle ended June 26. The second crop cycle with cultivar 'Lausanne' (Rijk Zwaan) started June 28 with a plant density of 2.25 plants $\mathrm{m}^{-2}$ and ended November 1 . Grower 2 transplanted January 9 cucumber plants of the cultivar 'Hi-Power' with a density of 1.65 plants $\mathrm{m}^{-2}$, doubled to 3.3 stems $\mathrm{m}^{-2}$ in February with last harvest July 4. The second crop cycle started July 6 ('Hi-Power') with a plant density of 2.2 plants $\mathrm{m}^{-2}$. The second crop cycle ended November 8.

\section{RESULTS}

\section{Greenhouse light transmission and light sum}

The results of the transmission measurements using the PAR grid show that especially on days with diffuse light conditions, the earlier ray-tracing calculations were very accurate. Figure 2 shows the calculated and measured transmission of the greenhouse in diffuse light conditions. The measured line shows the average of the 12 PAR sensors. The difference between the calculation and the measurement is less than 3\%. The jumps in the graph are caused by the opening and closing of the 2 transparent screens. The difference on sunny days is, as expected, bigger, which is most likely a result of reflections inside the greenhouse. On sunny days, sometimes several of the 12 sensors measured a higher intensity than outside. In the summer when there is plenty of ventilation and vents are opened far, a sensor can be illuminated directly by the sun. The deviation is also greater in the early morning at low solar elevation (data not shown). The calculations show a good match with the measurements. Subsequently, the annual light sum at crop level (below the screens) was calculated based on the screen positions and the weather conditions for the winter light greenhouse and two commercial greenhouses. This is shown in Figure 3, showing the growing period from the end of December to the beginning of November only. On an annual basis the crop in the Winterlight greenhouse received about $12 \%$ more light than the commercial greenhouses, but in the winter period (October to March) the differences are small. This is caused by the chosen screen strategy of the Winterlight greenhouse which differed from the commercial companies. 
Next to light transmission, energy saving was an item in the test facility. This resulted in a more intensive use of the screens (thus lower light levels, but higher energy savings). In addition, the Winterlight greenhouse has a dehumidification installation that makes it possible to control the air humidity under closed screens. In practice, growers often must open the screens partially to limit the humidity. On an annual basis, $50 \%$ more screen hours were made in the test facility. The total amount of hours with both screens closed is 7000 , 3500 and 4100, respectively, for the Winter light greenhouse and grower 1 and 2. The differences in the use of the screens compared to the commercial growers, are specially in the period April and May and September and October. This is hence to the possibility of using a dehumidification unit where the commercial growers decide not to use the screen to avoid humidity problems.

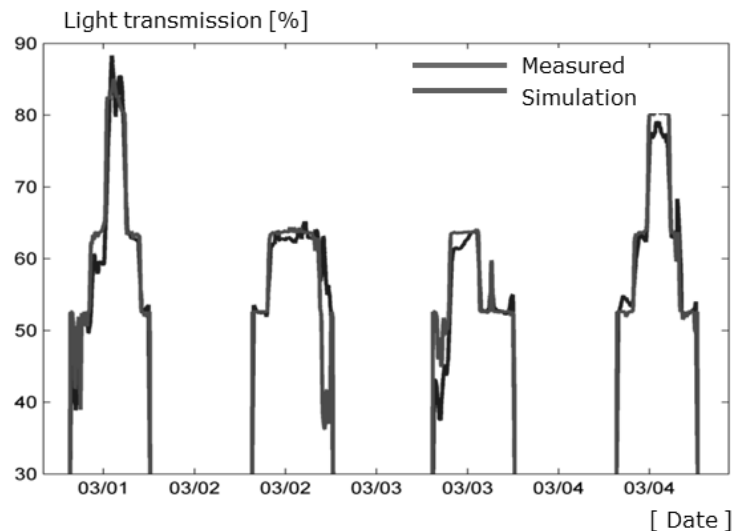

Figure 2. Calculated and measured transmission of the greenhouse in diffuse weather conditions between March 1 and March 4, 2017.

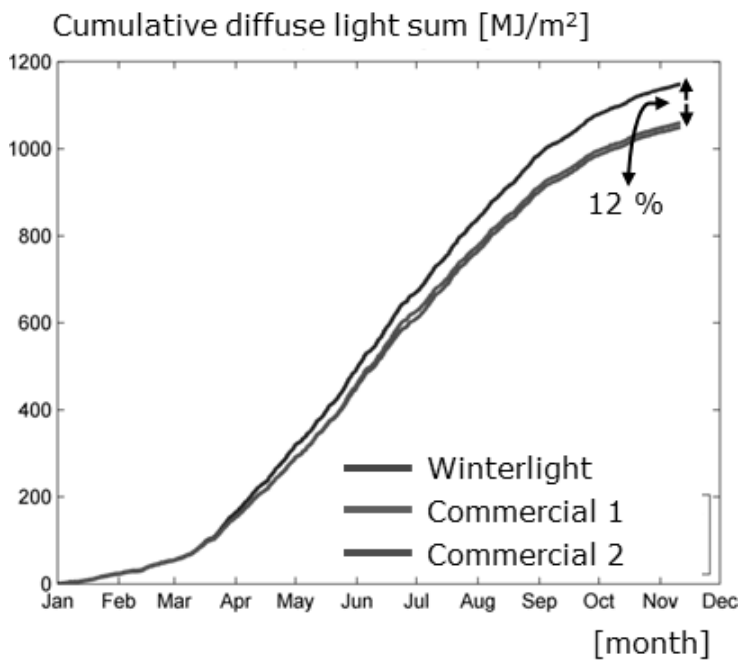

Figure 3. Calculated cumulative diffuse solar light sum at crop level of the Winterlight greenhouse and two commercial companies according to the Bleiswijk weather conditions and the screen control as used in the separate greenhouses.

In summer, the screen is also used as a shading screen if the global radiation exceeds $700 \mathrm{~W} \mathrm{~m}^{-2}$. Above this value the screen is closed for $80 \%$. These conditions vary per period and differ between the Winterlight greenhouse and the commercial growers. Figure 3 also shows that the total light sum of the winter period is very small compared to the summer. Although the figure does not show this clearly, there is also a difference in light sum between 
the two companies in the winter period. At the end of March, the cumulative difference was $9 \%$ on a total of $150 \mathrm{MJ} \mathrm{m}^{-2}$.

\section{Dehumidification}

The dehumidification unit has a maximum capacity of $9 \mathrm{~m}^{3} \mathrm{~m}^{-2} \mathrm{~h}^{-1}$, but this maximum capacity was almost never reached during the $1800 \mathrm{~h}$ that the unit was used. Figure 4 shows an annual load duration curve of the unit's use based on the fan speed. The figure shows that the unit has only run at full capacity for $75 \mathrm{~h}$ and by far the most hours at the minimum capacity. During those hours when the fans were running at minimum, the valve controlling the supply of outside air is between 50 and $100 \%$. The unit has a capacity (inlet) of $4550 \mathrm{~m}^{3}$ $\mathrm{h}^{-1}$ or around $9 \mathrm{~m}^{3} \mathrm{~m}^{-2} \mathrm{~h}^{-1}$. The electricity consumption varies between 0.1 and $2.5 \mathrm{~W} \mathrm{~m}^{-2}$ of greenhouse per fan depending on the fan speed. Because most operating hours were at minimum, the total electricity consumption remained below $2 \mathrm{kWh} \mathrm{m}^{-2}$ on an annual basis. Reheating has cost not more than $3.5 \mathrm{kWh} \mathrm{m}^{-2}$ of heat.

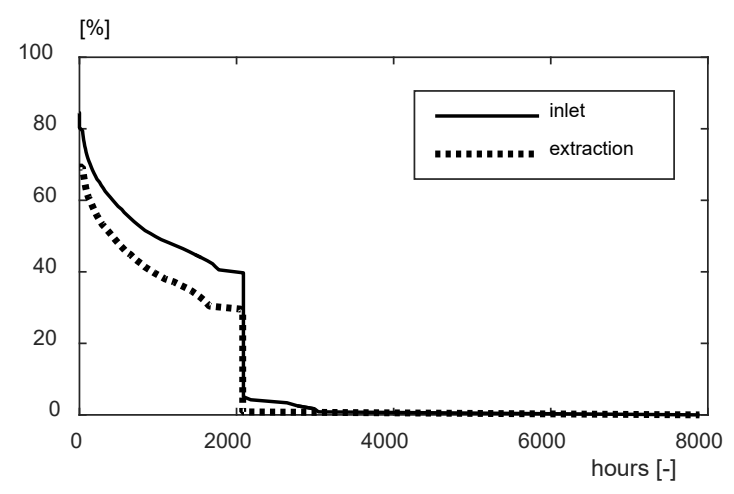

Figure 4. Annual load duration curve of the fans of the air handling unit during cultivation.

\section{Energy and climate}

The commercial companies did not have exactly the same growing period. Grower 2 started 2 weeks later but also stopped a little later. Figure 5 shows the 24-h average greenhouse air temperature during the cultivation period of the Winterlight greenhouse, grower 1 and grower 2 . In the period March to the end of the first crop (mid-June), the 24-h temperature in the winter light greenhouse is significantly higher than the commercial growers. The temperature peaks of grower 2 are somewhat lower than that of grower 1 because the location of grower 2 is closer to the coast and therefore has a somewhat lower outside temperature. The differences in 24-h temperature are mainly achieved by higher temperatures in the middle of the day when the sun heats the greenhouse. The temperatures in the night in the Winterlight greenhouse are equal to slightly lower than in the commercial companies. This strategy, together with the intensive use of screens and the relatively energyefficient dehumidification, helps to significantly reduce the energy consumption of the Winterlight greenhouse. Compared to the commercial growers, more than $40 \%$ less energy has been used, as shown in Figure 6. It is not surprising that the differences are not achieved in the middle of the winter but between April and October. The greenhouse of grower 1 is with regard to expected energy consumption in relation to the greenhouse equipment with 2 movable screens, comparable to the Winterlight greenhouse. That is the reason that in the winter, when the heating system has to maintain the temperature in the greenhouse, small differences occurred between the Winterlight greenhouse and grower 1 . That is also the period that humidity is not a problem and the screen use is therefore also a consequence of the crop that is still developing. The differences in spring, summer and early fall are mainly caused by large differences in screen use and the application of minimum heating pipe temperatures at the commercial companies, among other things as to be able to guarantee the 
$\mathrm{CO}_{2}$ dosage. The total heat consumption is 185,321 and $326 \mathrm{kWh} \mathrm{m}^{-2}$ for the Winterlight greenhouse and grower 1 and 2, respectively. The high energy saving in the winter light greenhouse, mainly in spring, summer and early autumn results in an additional need for $\mathrm{CO}_{2}$. In total $10.2 \mathrm{~kg} \mathrm{CO}_{2}$ of an alternative source was used.

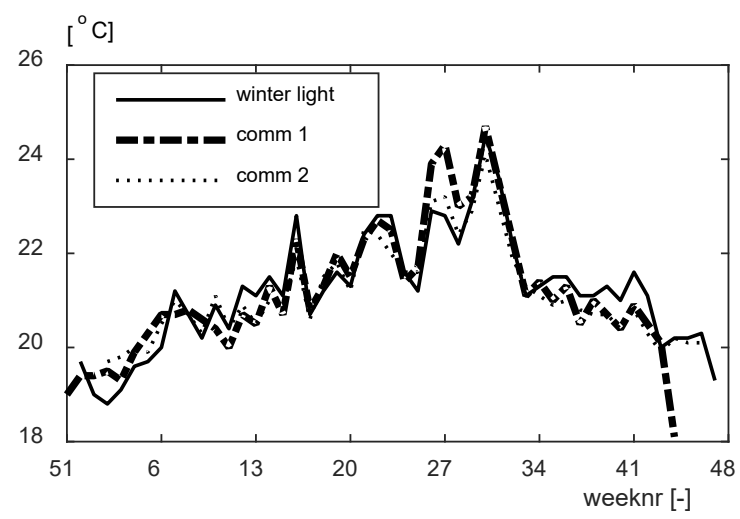

Figure 5. Daily average greenhouse air temperature during the cultivation period of the Winterlight greenhouse, comm 1 and comm 2.

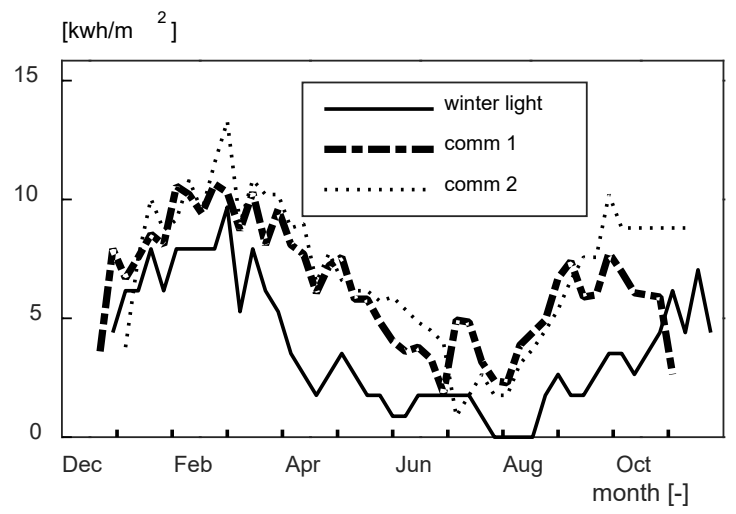

Figure 6. Weekly heat consumption during the cultivation period of the Winterlight greenhouse, comm 1 and comm 2.

\section{Re-rooting}

The first new root tips were visible a few days after placing the stems in the organic substrate, but it takes a very long time before the new roots take over the functionality of the original roots. After 3, 4 and 5 months after re-rooting, 10, 65 and $95 \%$ of the first stem part is respectively died. The stems therefore continued to function for a long time. The stems dried out when dying. The new roots mostly grew in the stone wool, which is clearly shown in Figure 7 , where the tray was drawn at the end of the cultivation of the substrate slab. The result of the re-rooting per individual stem varies greatly from very good root development to moderate root development. The result of the first re-rooting on April 26 was clearly better than on June 14. Possible cause for this can be found in the leaf axillary: if the leaf is cut too close to the stem there is less room for root formation. Currently, $100 \%$ coco fibre is used, while a mixture of coconut and perlite may form a better substrate for rooting, because of prevention of too wet substrate in the last cultivation phase with a higher risk on root diseases, e.g., Pythium. 


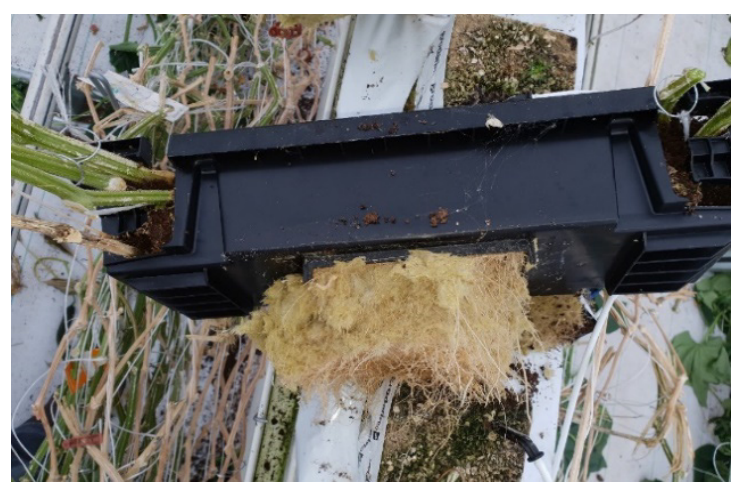

Figure 7. The fusion of the root sprout out of the re-root tray into the stone wool slab.

\section{Production}

The cumulative production is shown in Figure 8. The figure shows that the gain achieved in the summer by the continuous production compared to the growers who change crops has never been caught up. It can be seen that the lead diminishes somewhat in the second half of the year since it turned out that the old plants had a more irregular setting. The total production was 282, 245 and 224 first class cucumber fruits $\mathrm{m}^{-2}$ for the Winterlight greenhouse, grower 1 and 2, respectively. With an average fruit weight of 425, 407 and $403 \mathrm{~g}$ piece-1 $^{-1}$, the total kilo production reached 120,100 and $91 \mathrm{~kg} \mathrm{~m}^{-2}$. An annual production of 100 $\mathrm{kg} \mathrm{m}^{-2}$, as of grower 1, can be considered to be a good production. The production of grower 2 has lagged somewhat behind due to some virus attack and Pythium challenges. The realized production level in the Winterlight greenhouse was very high compared to other growers in the Netherlands.

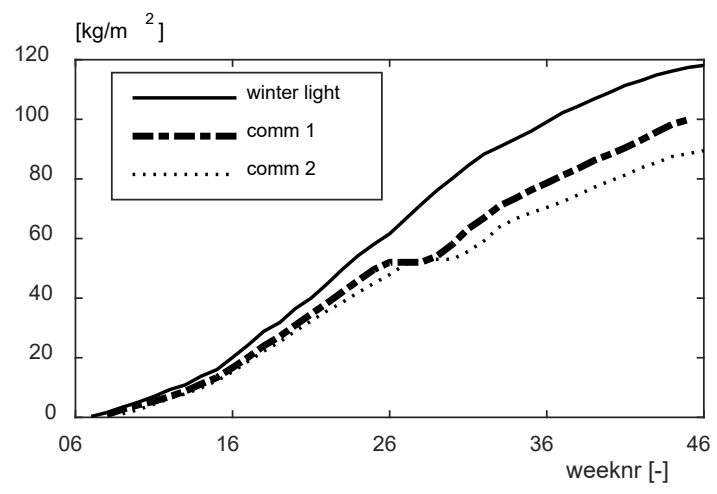

Figure 8. The cumulative kg production of the experiment in the Winterlight greenhouse and of comm 1 and comm 2.

\section{CONCLUSIONS}

Experiments in the Winterlight greenhouse have shown that high crop production in combination with low energy consumption can be achieved. An energy saving of more than $40 \%$ has been achieved in comparison to conventional growers. The high production is a result of novel greenhouse design resulting in a 10\% higher PAR sum at crop level. Thanks to re-rooting a production gap in mid-summer has been prevented resulting in a very high total production and quality.

Model simulations of the greenhouse transmission were initially used in the design phase and show a good match with an average measured transmission by a grid of PAR sensors, especially under diffuse light conditions. 


\section{ACKNOWLEDGEMENTS}

The research is carried out together with a consortium of greenhouse suppliers: Bom Group, Glascom, BASF (formerly Bayer, Nunhems) and Ludvig Svensson and is co-financed by the Dutch Ministry of Agriculture in the scope of the Dutch research programme for energy saving 'Kas als Energiebron'. Special thanks to the growers Jan Reijm and Jaco den Bakker who advise us every second week by visiting the experiment and providing their data.

\section{Literature cited}

Dueck, T.A., Janse, J., Li, T., Kempkes, F.L.K., and Eveleens, B.A. (2012). Influence of diffuse glass on the growth and production of tomato. Acta Hortic. 956, 75-82 https://doi.org/10.17660/ActaHortic.2012.956.6.

Hemming, S., Waaijenberg, D., Bot, G.P.A., Dueck, T., Van Dijk, C., Dieleman, A., Van Rijssel, E., Houter, B., Sonneveld, P.J., de Zwart, H.F., and Marissen, N. (2004). Optimale lichtomstandigheden bij de transitie naar een energiezuinige kastuinbouw. WUR Report 100. Agrotechnology and Food Innovations.

Hemming, S., Dueck, T.A., Janse, J., and van Noort, F.R. (2008). The effect of diffuse light on crops. Acta Hortic. 801, 1293-1300 https://doi.org/10.17660/ActaHortic.2008.801.158.

Hemming, S., Kempkes, F.L.K., and Mohammadkhani, V. (2011). New glass coatings for high insulating greenhouses without light losses - energy saving crop production and economic potentials. Acta Hortic. 893, 217-226 https://doi.org/10.17660/ActaHortic.2011.893.15.

Janssen, E.G.O.N., Oversloot, H., van der Wiel, W.D., and Zonneveldt, L. (2006). Optimaal kasdek TNO-rapport 2004BC-R0060.

Kempkes, F., De Zwart, H.F., Munoz, P., Montero, J.I., Baptista, F.J., Giuffrida, F., Gilli, C., Stepowska, A., and Stanghellini, C. (2017). Heating and dehumidification in production greenhouses at northern latitudes: energy use. Acta Hortic. 1164, 445-452 https://doi.org/10.17660/ActaHortic.2017.1164.58.

Kempkes, F., Swinkels, G.J., and Hemming, S. (2018). Increase of light transmission of a Venlo-type greenhouse during winter by 10\%: a design study. Acta Hortic. 1227, 133-140 https://doi.org/10.17660/ActaHortic. 2018.1227.16.

Li, T., Heuvelink, E., Dueck, T.A., Janse, J., Gort, G., and Marcelis, L.F.M. (2014). Enhancement of crop photosynthesis by diffuse light: quantifying the contributing factors. Ann. Bot. 114 (1), 145-156 https://doi.org/10.1093/aob/ mcu071. PubMed

Marcelis, L.F.M., Buwalda, F., Dieleman, J.A., Dueck, T.A., Elings, A., de Gelder, A., Hemming, S., Kempkes, F.L.K., Li, T., van Noort, F., and de Visser, P.H.B. (2014). Innovations in crop production: a matter of physiology and technology. Acta Hortic. 1037, 39-45 https://doi.org/10.17660/ActaHortic.2014.1037.1.

Stanghellini, C., Bruins, M.A., Mohammadkhani, V., Swinkels, G.L.A.M., and Sonneveld, P.J. (2012). Effect of condensation on light transmission and energy budget of seven greenhouse cover materials. Acta Hortic. 952, 249254 https://doi.org/10.17660/ActaHortic.2012.952.30. 
